\title{
Актуальні питання стану та тенденції розвитку дослідницьких робіт за напрямком «Дитяча діабетологія»
}

М.Л. Водолажський ${ }^{\text {, }}$ Т.П. Сидоренко', Т.В. Фоміна', T.B. Кошман ${ }^{1}$

1 ДУ «Інститут охорони здоров'я дітей та підлітків Національної академії медичних наук України», м. Харків

${ }^{2}$ Харківський національний університет ім. В.Н. Каразіна

Резюме. Мета - вдосконалення науково-інформаційного забезпечення фахівців галузі охорони здоров'я дітей і підлітків за напрямком «Дитяча ендокринологія». Матеріал і методи. Дослідження проводили за даними бази рефератів звітів науково-дослідних (39) і дисертаційних робіт (79), які проведено в Україні 2001-2017рр. з актуальних питань дитячої ендокринології, з використанням семантичного, інформаційного, наукометричного, бібліографічного, патентного, статистичного методів. Для вивчення інформованості лікарів щодо наукового продукту, створеного за напрямком «Дитяча ендокринологія», використано розроблений авторами опитувальник. Результати. У статті наведено дані про розвиток дослідницького процесу за напрямками дитячої ендокринології протягом тривалого терміну (20012017 рр.). Визначено кількісні показники збільшення проведення науково-дослідних і дисертаційних робіт, їх тематичну спрямованість, обсяг і структуру створеного наукового продукту, його використання фахівцями з дитячої ендокринології. Висновки. В Україні стабільно здійснюється дослідницький процес за актуальними напрямками дитячої ендокринології, у тому числі діабетології, створюється відповідний інформаційний та інноваційний ресурс, основним змістом якого є: вдосконалення ранньої діагностики цукрового діабету, визначення чинників ризику його виникнення в дітей і підлітків, розробка терапії згідно з протоколами лікування цього контингенту хворих, удосконалення диспансерного нагляду, навчання хворих на цукровий діабет принципам самоконтролю, реабілітація дітей і підлітків у санаторно-курортних умовах. Надзвичайно важливим $є$ подальший розвиток наукометричних досліджень за напрямком дитячої ендокринології для вибору перспективних і пріоритетних досліджень, моніторинг дослідницьких розробок і науково-технічної продукції для вдосконалення впровадження результатів досліджень у практику дитячих ендокринологів, оптимізації їх науково-інформаційного забезпечення.

Ключові слова: дитяча ендокринологія, дослідницькі роботи, діабетологія, діти та підлітки.

* Адреса для листування (Correspondence): ДУ «Інститут охорони здоров'я дітей та підлітків НАМН України», пр. Ювілейний, 52А, м. Харків, 61153, Україна. E-mail: iozdpn@gmail.com.

○ М.Л. Водолажський, Т.П. Сидоренко, Т.В. Фоміна, Т.В. Кошман 
Підставою для проведення профілактичних, лікувальних і реабілітаційних програм медичного супроводу дітей і підлітків, які хворіють на цукровий діабет, є рекомендації ВООЗ [1], які ретельно викладено на відповідному сайті в Глобальному докладі (who.inf) і Програмі із цукрового діабету [1].

Програму ВООЗ стосовно діабету спрямовано на профілактику, мінімізацію виникнення ускладнень цього захворювання та підвищення якості життя хворих. Метою Програми є поліпшення здоров'я пацієнтів шляхом здійснення ефективних заходів з епіднадзору, профілактики та лікування діабету та його ускладнень, надто в країнах із низьким і середнім рівнем розвитку. Для досягнення цієї мети особливу увагу в документах приділено таким основним заходам: спостереження за розробкою та прийняттям погоджених на міжнародному рівні стандартів діагностики та лікування діабету та його ускладнень, проведення досліджень чинників ризику його виникнення тощо [1].

В Україні проблемам ендокринних захворювань у дітей і підлітків приділяється багато уваги. За даними науковців ДУ «ІОЗДП НАМН», відсоток дослідницьких робіт із питань дитячої ендокринології дорівнює 12,75\% у загальній структурі досліджень проблем охорони здоров'я підростаючого покоління. Частка дисертаційних робіт з актуальних проблем цукрового діабету серед цього масиву документів становить 59,49\%. Також зафіксовано зростання показників поширюваності цукрового діабету серед дітей і підлітків у середньому на 2,5\% за рік. За прогнозом багатьох учених, показники даної патології серед цього контингенту населення в країні з часом будуть зростати та досягнуть 10,8\% у структурі захворюваності [2-6].

Для підвищення якості медичного забезпечення хворих на цукровий діабет на етапах первинної та вторинної медико-санітарної допомоги розроблено низку нормативно-правових документів, що окреслюють компетенції всіх фахівців, які беруть участь у лікувально-реабілітаційних заходах для цих хворих. В їх числі: національні стандарти лікування та реабілітації (протоколи лікування, відповідні накази МОЗ України), а саме: протокол надання медичної допомоги в галузі медицини «Дитяча ендокринологія» («Цукровий діабет 1-го типу», «Цукровий діабет 2-го типу», «Хронічні ускладнення цукрового діабету», «Діабетична нефропатія», «Діабетична ретинопатія», «Діабетична невропатія», «Санаторно-курортне лікування дітей, хворих на цукровий діабет», додаток до Наказу МОЗ № 364 від 28.05.2009 «Клінічний протокол санаторно-курортного лікування«), які опубліковані на відповідних сайтах МОЗ.

За результатами інформаційно-аналітичного аналізу публікацій з актуальних проблем медичного забезпечення дітей і підлітків, хворих на цукровий діабет, встановлено, що більшу їх частину присвячено питанням розробки нових медичних технологій лікування цієї патології серед дитячого та підліткового контингенту: створення нових лікарських засобів, впровадження високотехнологічних методів (інсулінових помп), розробка методів контролю вмісту глюкози в крові [7-9].

Активно досліджуються та обговорюються питання відновного лікування дітей і підлітків із цукровим діабетом в умовах санаторних закладів. Ще одним із тематичних напрямків публікацій з актуальних проблем медичного забезпечення цих пацієнтів є їх медико-соціальна реабілітація, яка передбачає соціальну підтримку родини, психологічний супровід, заняття в школах самоконтролю цукрового діабету. Особлива увага дослідників приділяється запобіганню розвитку ускладнень цієї хвороби та пропаганді здорового способу життя [10-12].

Водночас є доцільним ретельніше дослідити стан і тенденції розвитку дослідницького процесу із цих питань в Україні.

Мета роботи - вдосконалення науково-інформаційного забезпечення фахівців галузі охорони здоров’я дітей і підлітків за напрямком «Дитяча діабетологія».

\section{Матеріал і методи}

Дослідження проводили за даними бази рефератів звітів науково-дослідних і дисертаційних робіт (за спеціальностями 14.01.14 «Ендокринологія» та 14.01.10 «Педіатрія«), зареєстрованих в УкрIHTEI 2001-2017 роками. Відбір документів здійснювали за ключовими словами та словосполученнями: дитяча ендокринологія, цукровий діабет, патологія щитоподібної залози, фізичний і статевий розвиток, ожиріння, школярі, діти та підлітки. Усього відібрано 39 рефератів звітів науково-дослідних 
робіт (НДР) і 79 рефератів дисертаційних робіт (ДР), проведених в Україні в досліджуваний період. Аналіз інформаційних та інноваційних ресурсів дослідницьких робіт, наданих в облікових картках, проводили за допомогою семантичного, інформаційного, наукометричного, бібліографічного, патентного, статистичного методів.

Для вивчення інформованості лікарів щодо наукового продукту, створеного за напрямком «Дитяча ендокринологія», використано розроблений авторами опитувальник. Анкету створено як інструмент для дослідження ступеня впровадження нових медичних технологій, що стосуються діагностики, лікування, профілактики та реабілітації дітей і підлітків з ендокринною патологією. Вона містить 18 розділів. Окрім паспортних і професійних даних, є 10 питань щодо використання інформаційного та інноваційного ресурсів: комунікаційних каналів передачі, шляхів впровадження, форм зв’язку науковців із лікарями, можливостей комерційних видів трансферу. Опитувальник пройшов апробацію серед лікарів-ендокринологів (50) поліклінік, ендокринологічних клінічних відділень науково-дослідних інститутів, ендокринологічних диспансерів із семи областей України. Статистичний аналіз здійснювали за допомогою програми SPSS Statistics v17.0.

\section{Результати та обговорення}

Аналіз обсягу дослідницьких робіт (НДР і ДР), проведених в Україні 2001-2017 роками за тематичними напрямками дитячої ендокринології, свідчить про збільшення кількості НДР за напрямками дитячої ендокринології в 1,5 раза (табл.). Також відзначено збільшення кількості ДР за спеціальністю 14.01.10 «едіатрія» у 2,5 раза та за спеціальністю 14.01.14 «Ендокринологія». Відсоток досліджень у цьому напрямку в структурі усіх дослідницьких робіт із питань охорони здоров'я дітей і підлітків дорівнює $12,75 \%$. За результатами інформаційного аналізу відсоток досліджень ДР з актуальних проблем цукрового діабету становив 59,49\%. Важливо відзначити, що за тематичними напрямками дитячої ендокринології в цей період виконувалось дисертаційних досліджень майже однакова кількість за спеціальностями 14.01.10 і 14.01.14 (табл.).
Таблиця. Обсяг дослідницьких робіт, проведених в Україні 2001-2017 роками за тематичними напрямками дитячої ендокринології

\begin{tabular}{|c|c|c|c|c|c|c|c|c|}
\hline \multirow{3}{*}{$\begin{array}{l}\text { Види дослід- } \\
\text { ницьких робіт }\end{array}$} & \multicolumn{6}{|c|}{ Роки дослідження } & \multirow{2}{*}{\multicolumn{2}{|c|}{ Усього }} \\
\hline & \multicolumn{2}{|c|}{$\begin{array}{l}2001- \\
2005 \\
\end{array}$} & \multicolumn{2}{|c|}{$\begin{array}{l}2006- \\
2010\end{array}$} & \multicolumn{2}{|c|}{$\begin{array}{l}2011- \\
2017\end{array}$} & & \\
\hline & $\mathbf{n}$ & $\%$ & $\mathbf{n}$ & $\%$ & $\mathbf{n}$ & $\%$ & $\mathbf{n}$ & $\%$ \\
\hline НДР & 10 & 25,64 & 14 & 35,90 & 15 & 38,50 & 39 & 100 \\
\hline $\begin{array}{l}\text { ДР за спеціаль- } \\
\text { ністю 14.01.10 }\end{array}$ & 8 & 19,00 & 14 & 33,30 & 20 & 47,61 & 42 & 100 \\
\hline $\begin{array}{l}\text { ДР за спеціаль- } \\
\text { ністю 14.01.14 }\end{array}$ & 8 & 21,67 & 8 & 21,67 & 21 & 56,75 & 37 & 100 \\
\hline
\end{tabular}

Аналіз тематичної спрямованості дослідницьких робіт дозволив визначити відсоток досліджень, присвячених актуальним питанням дитячої діабетології.

Тематичну спрямованість дослідницьких робіт (НДР і ДР) наведно на рис. 1.
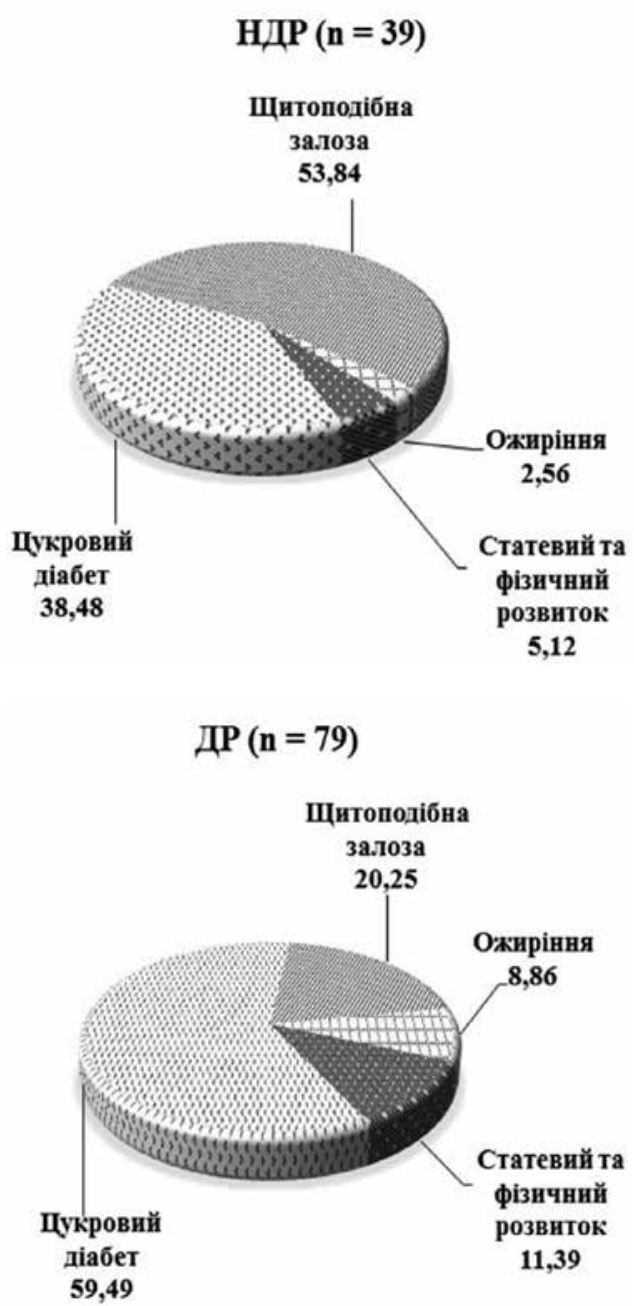

Рис. 1. Структура тематичних напрямків наукових робіт, проведених в Україні 2001-2017 роками в дитячій ендокринології (\%). 
Оригінальні дослідження

У досліджуваний період (2001-2017 рр.) найбільше виконувалось ДР із проблем цукрового діабету та патології щитоподібної залози як за спеціальністю 14.01.14 «Ендокринологія», так і за спеціальністю 14.01.10 «Педіатрія». Важливо відзначити, що тематика ДР виходить за межі вузьких питань суто дитячої ендокринології, що свідчить про інтерес дослідників до проблем коморбідності патологічних станів. Тому кількість ДР виявилася дещо вищою, ніж НДР.

Проведено кількісний аналіз первинних наукових документів, які формують інформаційні та інноваційні ресурси наукових досліджень із питань цукрового діабету (рис. 2). Він показав, що в структурі інформаційних документів за всі роки спостереження (2001-2017рр.) тези доповідей посідають першу рангову позицію, статті - другу позицію, книжкові видання - третю позицію. У структурі інноваційних ресурсів перше місце посіли патенти на винаходи та корисні моделі, друге - методичні рекомендації, третє - авторські свідоцтва на наукові праці, комп'ютерні програми та бази даних.

Результати опитування фахівців щодо використання наукового продукту, створеного в дитячій ендокринології (рис. 3), свідчить, що найбільший попит серед них сьогодні мають: методичні рекомендації; далі йдуть підручники, посібники, довідники та покажчики; клінічні протоколи/стандарти, настанови діагностики, лікування, реабілітації; статті у вітчизняних наукових виданнях, довідники, покажчики. Далі, у порядку зменшення значущості наукових комунікацій для фахівців, йдуть: інформаційні листи, статті в зарубіжних наукових виданнях; монографії, оглядова інформація; Інформацій-

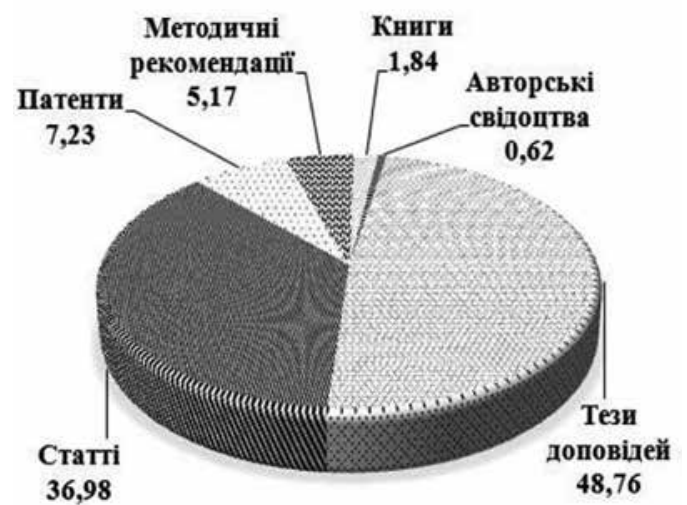

Рис. 2. Кількісні показники інформаційних та інноваційних ресурсів, створених за результатами НДР 2001-2017 роками за напрямками дитячої ендокринології (\%).

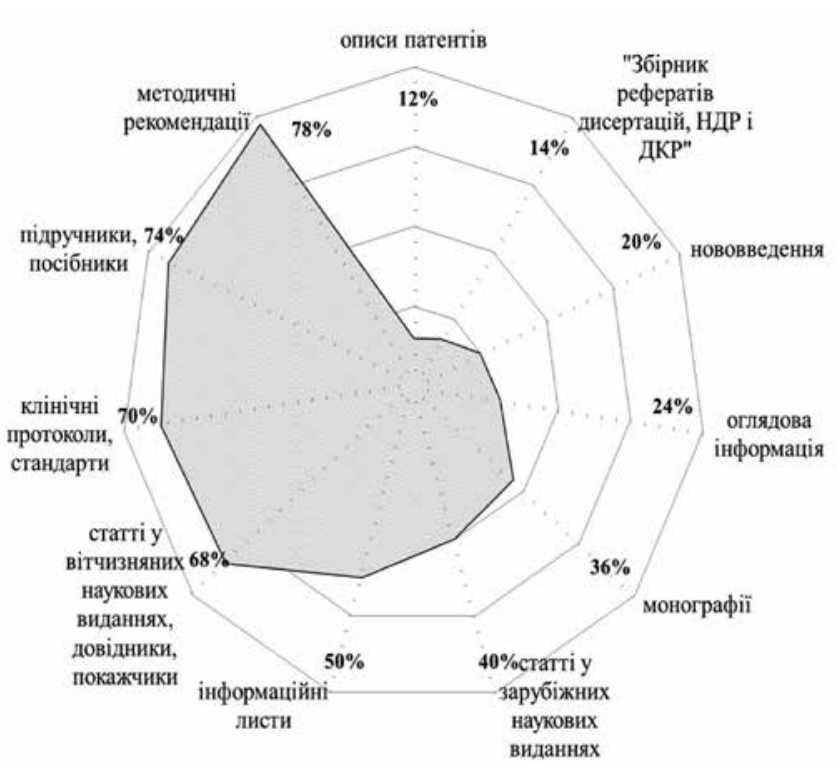

Рис. 3. Структура та ступінь використання в роботі фахівців наукової продукції, створеної за результатами дослідницьких робіт.

ний бюлетень нововведень НАМН України та Реєстр галузевих нововведень МОЗ України (Перелік наукової та науково-технічної продукції, призначеної для впровадження досягнень медичної науки у сферу охорони здоров'я МОЗ України). Найменше фахівці використовують «Збірник рефератів дисертацій, НДР і ДКР» та описи патентів.

Також за результатами опитування фахівців з'ясовано суттєве збільшення значущості для них безперервної медичної освіти для підвищення власної кваліфікації та наукових ресурсів мережі Інтернет.

\section{Висновки}

1. В Україні стабільно проводяться дослідження за актуальними напрямками дитячої ендокринології, у тому числі діабетології, зафіксовано збільшення їх кількості.

2. Основним змістом створеного інформаційного та інноваційного ресурсів дослідницьких робіт є: вдосконалення ранньої діагностики цукрового діабету, визначення чинників ризику його виникнення в дітей і підлітків, розробка терапії згідно з протоколами лікування цього контингенту хворих, удосконалення диспансерного нагляду, навчання хворих на цукровий діабет принципам самоконтролю, реабілітація дітей і підлітків у санаторно-курортних умовах. 
3. Результати опитування фахівців свідчать про активне використання наукового продукту, створеного в дитячій ендокринології.

4. Надзвичайно важливим є подальший розвиток наукометричних досліджень за напрямком дитячої ендокринології для вибору перспективних і пріоритетних досліджень, моніторинг дослідницьких розробок і науковотехнічної продукції для вдосконалення впровадження результатів досліджень у практику дитячих ендокринологів, оптимізації їх науково-інформаційного забезпечення.

Конфлікт інтересів відсутній.

\section{Список використаної літератури}

1. Глобальный доклад по диабету. 2018. [Internet]. http://apps. who.int/iris/bitstream/handle/10665/275388/9789244565254rus.pdf?ua $=1$. (Global report on diabetes).

2. Лук'янихін ВО. та ін. Екологічно-орієнтовані стратегії управління соціально-економічним розвитком території: звіт про НДР (заключний). Суми: СумДУ, 2014:144. (Luk'yanykhin VO. Ecologically oriented strategies for management of socio-economic development of the territory: the report on the research scientific work (final))

3. Лисак ВП, Ковальова ОМ, Похилько ВІ, Черевко ІГ. Тренди поширеності та захворюваності на цукровий діабет Полтавської області за 2008-2014 рр. Здоров'я населення: тенденція та прогноз. 2015;3(35):20-3. (Lysak VP, Koval'ova OM, Pokhyl'ko VI Cherevko IH. Trends in the prevalence and incidence of diabetes mellitus in the Poltava region for 2008-2014. Public health: trend and forecast).

4. Маньковський БМ, Ткаченко ВI. Результати впровадження уніфікованого клінічного протоколу з надання медичної допомоги хворим на цукровий діабет 2 типу. Ендокринологія. 2014;19(4):323. (Man'kovs'kyy BM, Tkachenko VI. Results of the implementation of the unified clinical protocol for the provision of medical care to patients with type 2 diabetes).

5. Фастовець ММ. Цукровий діабет I типу у дітей: фактори, які провокують його виникнення (огляд літератури). Вісник проблем біології і медицини. 2016;1(2):28-33. (Fastovets MM Type I diabetes in children: factors provoking its occurrence (literary review)).

6. Морозов ОВ, Будрейко ОА. Оцінка фізичної активності у здорових та хворих на цукровий діабет дітей і підлітків (огляд літератури та власні дані). Проблеми ендокринної патології. 2013;4:78-87. (Morozov OV, Budreyko OA. Assessment of physical activity in healthy and diabetic children and adolescents (review and own results)).

7. Тронько МД. Пріоритетні питання діабетології в Україні на сучасному етапі та шляхи їх вирішення. 2016. [Internet]. http:// iem.net.ua/endocrinology task. (Tron'ko MD. Priority issues of diabetology in Ukraine at the present stage and ways of their solution).

8. Сахарный диабет: обеспечение пациентов в Европе. Что нужно изменить Украине? Еженедельник «Аптека». [Internet]. 2014.48(969). https://www.apteka.ua/article/315273. (Diabetes mellitus: providing patients in Europe. What should Ukraine change?).

9. Алимова ИЛ. Достижения и проблемы клинической практики детской диабетологии. Российский вестник диабетологии и педиатрии. 2013;2:4-11.(Alimova IL. Achievements and problems in pediatric clinical diabetology practice)

10. Кириллова ЕА. Когнитивно-поведенческая терапия в системе медико-психологической помощи подросткам, страдающим сахарным диабетом. Ендокринологія. 2014;19(4):303-04. (Kirillova EA. Cognitive-behavioral therapy in the system of medical and psychological assistance to adolescents suffering from diabetes)

11. Чумак СО, Будрейко ОА. Оцінка досвіду структурованого навчання хворих дітей і підлітків у школі цукрового діабету. Ендокринологія. 2014;19(4):362-63.(Chumak SO, Budreyko OA. Evaluation of the experience of structured training of sick children and adolescents in a school of diabetes mellitus).

12. Чумак СО, Цилюрик СМ. Особливості знань щодо своєї хвороби в дітей дошкільного та молодшого шкільного віку з цукровим діабетом 1 типу. Ендокринологія. 2014;19(4):364. (Chumak SO, Tsylyuryk SM. Peculiarities of knowledge in children of preschool and junior school age with type 1 diabetes with respect to their illness).

(Надійшла до редакції 04.06.2019р.)

\section{Актуальные вопросы состояния и тенденции развития исследовательских работ по направлению «Детская диабетология»}

\section{М.Л. Водолажский, Т.П. Сидоренко, Т.В. Фомина, Т.В. Кошман \\ ГУ «Институт охраны здоровья детей и подростков Национальной медицинской академии наук Украины», г. Харьков \\ Харьковский национальный университет им. В.Н. Каразина}

Резюме. Цель - совершенствование научно-информационного обеспечения специалистов отрасли охраны здоровья детей и подростков в направлении «Детская эндокринология». Материал и методы. Исследование проводено по данным базы рефератов отчетов научно-исследовательских (39) и диссертационных работ (79), проведенных в Украине в 2001-2017 гг. по актуальным вопросам детской эндокринологии, с использованием семантического, информационного, наукометрического, библиографического, патентного, статистического методов. Для изучения информированности врачей о научном продукте, созданном в направлении «Детская эндокринология», использован разработанный авторами опросник. Результаты. В статье приведены данные о развитии исследовательского процесса в направлениях детской эндокринологии в течение длительного периода (2001-2017 гг.). Определены показатели увеличения количества научно-исследовательских и диссертационных работ, их тематическая направленность, объем и структура созданного научного продукта, его использование специалистами детской эндокринологии. Выводы. В Украине стабильно осуществляется исследовательский процесс по актуальным направлениям детской эндокринологии, в том числе диабетологии, создается соответствующий информационный и инновационный ресурс, основным содержанием которого являются: совершенствование ранней диагностики сахарного диабета, определение факторов риска его возникновения у детей и подростков, разработка терапии согласно протоколам лечения этого контингента больных, совершенствование диспансерного наблюдения обучение больных сахарным диабетом принципам самоконтроля, реабилитация детей и подростков в санаторно-курортных условиях. Чрезвычайно важным является дальнейшее развитие наукометрических исследований по направлению детской эн- 
Оригінальні дослідження

докринологии для выбора перспективных и приоритетных исследований, мониторинг исследовательских разработок и научно-технической продукции для совершенствования внедрения результатов исследований в практику детских эндокринологов, оптимизации их научно-информационного обеспечения.

Ключевые слова: детская эндокринология, исследовательские работы, диабетология, дети и подростки.

\section{Urgent issues of the state and trends of the development of research works in pediatric diabetology direction}

\section{M.L. Vodolazhsky, T.P. Sidorenko, T.V. Fomina, \\ T.V. Koshman}

State Institution «Institute of Health Protection of Children and Adolescents of the National Academy of Medical Sciences of Ukraine», Kharkiv

V.N. Karazin Kharkiv National University

Abstract. The objective is to improve the scientific and informational support of specialists in the field of health care for children and adolescents in Pediatric Endocrinology direction. Material and methods. The study was carried out according to the base of the abstracts of research (39) and dissertation papers (79), conducted in Ukraine in 2001-2017 on topical issues of pediatric endocrinology on the basis of the use of semantic, informational, scientometric, bibliographic, patent and statistical methods. To study the awareness of physicians about the scientific product, created in Pediatric Endocrinology direction, the questionnaire developed by the authors was used. Results and discussion. The article presents data on the development of the research process in pediatric endocrinology direction over a long period (2001-2017). The quantitative indicators of the increase of scientific research and dissertation papers, their thematic orientation, volume and structure of the created scientific product, its use by specialists in pediatric endocrinology are shown. Conclusions. The results of the study indicate that the research process in Ukraine is consistently carried out in urgent directions of pediatric endocrinology, including diabetology, an appropriate information and innovation resource is being created, the main content of which is: improving the early diagnosis of diabetes, identifying risk factors for its occurrence in children and adolescents, the development of therapy according to the treatment protocols of this contingent of patients, the improvement of dispensary observation, training patients with diabetes on self-control principles, rehabilitation of children and adolescents in sanatorium conditions. Extremely important is the further development of scientometric study in the direction of pediatric endocrinology for the selection of promising and priority studies, monitoring of research developments and scientific and technical products to improve the implementation of research results in the practice of pediatric endocrinologists, optimizing their scientific information support.

Keywords: pediatric endocrinology, research paper, diabetology, children and adolescents. 